\title{
Care related to peripheral intravenous catheterism in pediatrics performed by nursing technicians
}

\author{
Cuidados relacionados ao cateterismo intravenoso periférico em pediatria realizados por técnicos de enfermagem
}

\section{Cuidados relacionados al cateterismo intravenoso periférico en pediatría realizados por técnicos de enfermería}

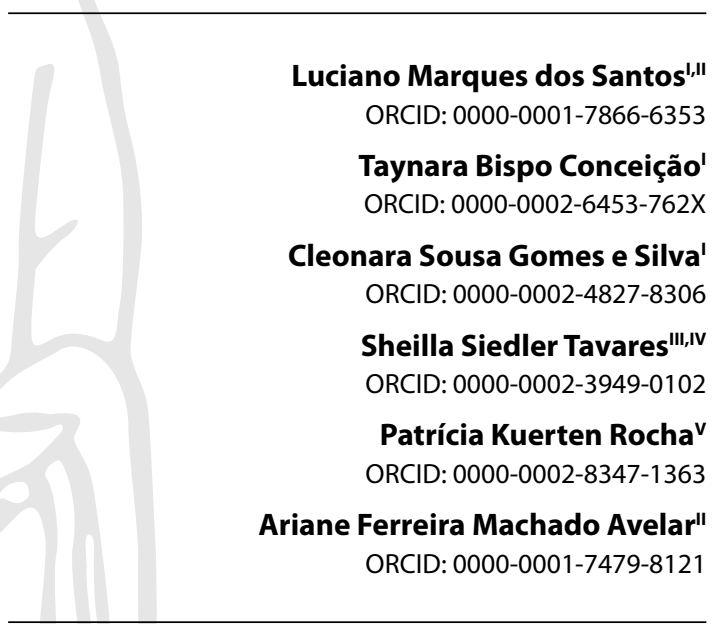

'Universidade Estadual de Feira de Santana. Feira de Santana, Bahia, Brazil.

"Universidade Federal de São Paulo. São Paulo,

São Paulo, Brazil.

I"Universidade Paulista. São Paulo, São Paulo, Brazil. "Universidade de Sorocaba. Sorocaba, São Paulo, Brazil. vUniversidade Federal de Santa Catarina. Florianópolis, Santa Catarina, Brazil.

How to cite this article: Santos LM, Conceição TB, Silva CSG, Tavares SS, Rocha PK, Avelar AFM. Care related to peripheral intravenous catheterism in pediatrics performed by nursing technicians. Rev Bras Enferm. 2022;75(2):e20200611. https://doi.org/10.1590/0034-7167-2020-0611

Corresponding author:

Luciano Marques dos Santos

E-mail: lucmarxenfo@yahoo.com.br

EDITOR IN CHIEF: Dulce Barbosa ASSOCIATE EDITOR: Rafael Silva

Submission: $07-18-2020$

Approval: 06-27-2021

\begin{abstract}
Objectives: to evaluate the care practice adopted by nursing technicians before, during and after peripheral intravenous catheterization performed in hospitalized children. Methods: cross-sectional and descriptive research, carried out in a pediatric hospital in Bahia through non-participatory observation of peripheral intravenous catheterizations performed in children by nursing technicians. Data was collected through an instrument containing care related to the moments before, during and after insertion of the catheter, calculating absolute and relative frequencies, measures of central tendency and dispersion. Results: there were 31 nursing technicians, who performed care mainly before intravenous catheterization. Nonconformities were identified regarding hand hygiene, use of a disposable mask, selection of the catheter insertion site, antisepsis, stabilization and catheter coverage. Conclusions: most of the precautions observed regarding peripheral intravenous catheterization are not in accordance with the standards of practice recommended by the national and international literature. Descriptors: Child Hospitalization; Catheterizations, Peripheral; Patient Safety; Pediatric Nursing; Care, Child.
\end{abstract}

\section{RESUMO}

Objetivos: avaliar a prática de cuidado adotada pelos técnicos de enfermagem antes, durante e após a cateterização intravenosa periférica realizada em crianças hospitalizadas. Métodos: pesquisa transversal e descritiva, realizada num hospital pediátrico da Bahia por meio de observação não participativa das cateterizações intravenosas periféricas realizadas em crianças por técnicos de enfermagem. Os dados foram coletados mediante um instrumento contendo os cuidados referentes aos momentos antes, durante e após a inserção do cateter, sendo calculadas frequências absolutas, relativas, medidas de tendência central e dispersão. Resultados: observaram-se 31 técnicos de enfermagem, que realizaram cuidados principalmente antes da cateterização intravenosa. Identificaram-se inconformidades quanto à higienização das mãos, uso de máscara descartável, seleção do sítio de inserção do cateter, realização da antissepsia, estabilização e cobertura do cateter. Conclusões: a maioria dos cuidados observados referentes à cateterização intravenosa periférica não estão de acordo com os padrões de prática recomendados pela literatura nacional e internacional. Descritores: Criança Hospitalizada; Cateterismo Periférico; Segurança do Paciente; Enfermagem Pediátrica; Cuidado da Criança.

\section{RESUMEN}

Objetivos: evaluar práctica de cuidado adoptada por técnicos de enfermería antes, durante y después de la cateterización intravenosa periférica realizada en niños hospitalizados. Métodos: investigación transversal y descriptiva, realizada en hospital pediátrico de Bahia mediante observación no participativa de cateterizaciones intravenosas periféricas realizadas en niños por técnicos de enfermería. Datos recolectados por instrumento conteniendo cuidados referentes a momentos antes, durante y después de la inserción del catéter, siendo calculadas frecuencias absolutas, relativas, medidas de tendencia central y dispersión. Resultados: observaron 31 técnicos de enfermería, que realizaron cuidados principalmente antes de la cateterización intravenosa. Identificaron inconformidades cuanto a higiene de manos, uso de mascarilla descartable, selección del local de inserción del catéter, realización de antisepsia, estabilización y cobertura del catéter. Conclusiones: mayoría de los cuidados observados referentes a cateterización intravenosa periférica no están de acuerdo con los estándares de práctica recomendados por la literatura nacional e internacional.

Descriptores: Niño Hospitalizado; Cateterismo Periférico; Seguridad del Paciente; Enfermería Pediátrica; Cuidado del Niño. 


\section{INTRODUCTION}

Peripheral intravenous catheterization (PIC) is performed in approximately $47.5 \%$ of hospitalized children for the infusion of drugs, solutions, blood products and nutrients ${ }^{(1-2)}$. However, data from 4,206 children from 278 hospitals in 47 countries, spread across the five continents, demonstrate that there is a global inconsistency with respect to care during the use of PIC in this population, which can lead to the occurrence of adverse events ${ }^{(3)}$.

Many of these adverse events are related to failures during vein selection, insertion, stabilization and coverage of the catheter, which can compromise the safety of care and contribute to potential complications at the catheterization site, especially infiltration $^{(2-6)}$, extravasation ${ }^{(5-6)}$, occlusion, phlebitis, infection ${ }^{(4-5)}$ and accidental removal of the device ${ }^{(5)}$. These resulting problems demand new catheter insertion attempts (sometimes without success), delay in the administration of prescribed intravenous therapy (IVT), damage to the vascular endothelium and emotional impact for the child, family and health professional, in addition to increased hospital costs and hospitalization time ${ }^{(7)}$.

Thus, it is essential to know the care provided by nursing professionals, in order to identify areas that require continuing education actions and the organization of local programs and policies that support evidence-based practice and, consequently, strengthen safe care.

In the Brazilian hospital context, it is clear that the IVT implementation process - including blood vessel selection, catheter insertion and maintenance, administration of drugs and solutions, as well as monitoring the occurrence of adverse events - is predominantly carried out by technical nursing professionals ${ }^{(8)}$.

It should be noted that, in the national scenario, the participation of nursing technicians in the nursing team is $77 \%{ }^{(9)}$ and they have their own training process, with a distinct set of activities ${ }^{(10)}$. The profession was consolidated with the enactment of Law No.5.692/71, and training is part of the Brazilian Educational System at the high school level, being regulated by Resolution No. 07/77 of the Federal Council of Education ${ }^{(11)}$, complying with the Exercise Law Nursing professional governed by the Federal Council of Nursing (COFEN) ${ }^{(11)}$.

The nursing technician is a member of the health team and is guaranteed a legal prerogative to assist the nurse at different times and processes ${ }^{(10)}$. In this context, Article 11 of the Law of Professional Nursing Practice in Brazil states that nurses have as their private activity the development of care of "greater technical complexity and that require scientifically-based knowledge and the ability to take immediate decisions"(12). Thus, it is understood that, due to its complexity, care related to the selection of the type of access, selection of the vein, insertion and maintenance of peripheral intravascular catheters, especially regarding the prevention of adverse events, should be exclusive to the nurse or be performed by the nursing technician only when under their direct supervision, especially in the pediatric population.

Therefore, as the nursing technician has a secondary level of education, they have the role of assisting the nursing team in carrying out care actions ${ }^{(12)}$. The catheterization technique is covered during his training, but he does not have in-depth knowledge about IVT, which is necessary to maintain the safety of the patient undergoing this therapy.
Despite verifying the importance of the nurse's direct participation in carrying out the PIC, COFEN resolutions that restrict the performance of the procedure by the nursing technician were not identified. This can be confirmed by a study that evaluated 364 resolutions developed by COFEN, of which only 15 briefly address the normative aspects of the nursing technician's performance. These resolutions support the work of these professionals in hemotherapy, chemotherapy, orthopedics, radiology, pre-hospital care, wounds, operating room, home and nutritional services ${ }^{(10)}$, without the explanation of the IVT.

However, international data indicate that $71 \%$ of catheters are inserted by nurses ${ }^{(3)}$, and this data is unknown in Brazil, which leads to the hypothesis that such intervention is generally performed by nursing technicians, since nurses are responsible for multiple managerial and administrative activities in your clinical practice ${ }^{(13)}$.

Thus, there is a need to verify how the PIC has been performed by nursing technicians, in order to seek subsidies for a safe practice. Thus, the guiding question of this study was: How do nursing technicians develop care before, during and after peripheral intravenous catheterization in hospitalized children?

\section{OBJECTIVES}

To evaluate the care practice adopted by nursing technicians before, during and after peripheral intravenous catheterization performed in hospitalized children.

\section{METHODS}

\section{Ethical aspects}

The research was approved by the Ethics and Research Committee of a public university in Bahia, and all professionals were aware of and agreed to participate in the research by signing the Informed Consent Form.

\section{Design, study site and period}

This is a cross-sectional and descriptive study, carried out at the medical clinic unit of a pediatric hospital in the state of Bahia, between April and June 2017. In this research, the recommendations of the tool Strengthening the Reporting of Observational Studies in Epidemiology were followed. (STROBE) ${ }^{(14)}$.

The study setting is characterized as a reference hospital in pediatric care of medium and high complexity in Bahia. The medical clinic unit of this institution has 29 beds for the hospitalization of children with chronic conditions of illness and infectious diseases, which in most cases require peripheral or central IVT. 36 nursing technicians, 6 assistant nurses and 1 nurse manager work in this unit.

After the medical prescription, the clinical nurses perform the calculations of the medications and/or solutions, prescribe the preparation and administration of the infusions, mainly the volume of medications or solutions, diluent and its volume, time and methods for infusion. Nurses are responsible for evaluating and indicating conducts related to more complex complications resulting from the use of IVT, such as extravasation. 
Upon detecting the need for PIC, nursing technicians perform the procedure autonomously, without nurse supervision or prior planning to obtain systematized venous access in order to remain until the end of treatment, according to the chemical characteristics of the solutions and medications and the time of use. Also, family members and children are not prepared for the procedure, as well as non-pharmacological measures for pain relief are not used.

$\mathrm{PIC}$ is performed using the traditional method, characterized by clinical assessment of the conditions of the venous network to be accessed with the intravenous catheter, regarding palpation and local inspection. When these workers are unable to obtain the intravenous route, the nurses on duty are called to try to perform the PIC.

\section{Population, inclusion and exclusion criteria}

Nursing technicians, chosen by the inclusion criteria, participated in the research: working as a nursing technician in the researched unit; be on the data collection shift scale; having more than two years of experience in the institution, because the researchers judged the time necessary for the nursing technicians to be familiarized with the environment; and having more than two years of experience in PIC in pediatrics, given that the routine performance of the procedure develops skills and helps professionals to perceive the actions they routinely adopt in the health service. Four observations of the PIC were excluded, as the professionals refused to continue in the research.

\section{Study protocol}

Before the research was carried out, there were no systematic discussions on the use of good practices in the insertion of peripheral intravenous devices in children and no protocols on IPC were made available in the researched sector.

To record the data, the authors created an instrument containing demographic and professional information from the person responsible for the PIC and the technical care recommended for carrying out this procedure by the Infusion Nurses Society (INS) ${ }^{(15)}$, INS Brazil ${ }^{(16)}$ and the National Surveillance Agency sanitary ${ }^{(17)}$.

The care observed and contained in the collection instrument were divided into: before (hand hygiene and assessment of the conditions of the venous network regarding visibility, palpability, path and mobility), during (use of personal protective equipment, area used for PIC, vein dilation, material used for venous dilation, use of sterile material, technique for antisepsis of the catheter insertion site - respect the time for drying the antiseptic used before the PIC attempt, touch the insertion site after completion antisepsis, stabilization and coverage of the catheter) and after (identification of the intravenous catheter and registration of the PIC in the child's medical record).

Before data collection, the project was presented to all team members, and the research's methodological procedures were explained, and any doubts answered. Duration was approximately two hours.

Afterwards, collection was started in the morning and afternoon shifts, between Monday and Friday, as the institution's rules did not allow this type of research activity on weekends or at night. The information was collected through a primary source obtained from systematic and non-participant observation (guided by the data collection instruments developed for this purpose) of nursing professionals while performing the PIC.

The collection was carried out by two researchers duly qualified for the technique of nonparticipant observation and for the application of the research instrument. It is noteworthy that these researchers had already performed data collection from another research in the same unit and with the same professionals, making the presence of the researcher a routine, which tends to maintain the behavior and the execution of activities in a natural way by the observing professionals.

Each selected professional was observed twice, in different shifts and with an interval of one week between observations, in order to assess the homogeneity of the conduct of each one when performing the PIC. This number of observations was defined by the researchers to reduce the chance of change in the behavior pattern of the researched professionals when performing care before, during and after the PIC when in the presence of the researchers, which would characterize the Hawthorne effect ${ }^{(18)}$, although the unit is continually used as a research setting.

\section{Analysis of results and statistics}

Data were tabulated in electronic spreadsheets and analyzed using the Statistical Package for Social Sciences (SPSS, version 22.0) program. Categorical variables were described using absolute and relative frequencies; and, for the numerical ones, measures of central tendency and dispersion (means and standard deviation) were calculated.

\section{RESULTS}

The observations were carried out with 31 nursing technicians, totaling 200 hours of observation. During the period of data collection, all demands related to the PIC were met by nursing technicians.

Most of the participants were aged between 36 and 40 years, were women, worked in the pediatric area from 6 to 10 years, and from 2 to 4 years in the researched unit (Table 1).

Table 1 - Characterization of nursing technicians participating in the research, Feira de Santana, Bahia, Brazil, April-June of 2017

\begin{tabular}{|c|c|c|c|}
\hline Variables & $\mathbf{n}(\%)$ & Mean & $\begin{array}{l}\text { Standard } \\
\text { Deviation }\end{array}$ \\
\hline \multicolumn{4}{|c|}{ Age of participants (years) } \\
\hline $25-30$ & $6(19.3)$ & \multirow{4}{*}{35.23} & \multirow{4}{*}{6.106} \\
\hline $31-35$ & $9(29)$ & & \\
\hline $36-40$ & $12(38.7)$ & & \\
\hline More than 40 & $4(13)$ & & \\
\hline \multicolumn{4}{|l|}{ Sex of participant } \\
\hline Female & $27(87)$ & & \\
\hline Male & $4(13)$ & & \\
\hline \multicolumn{4}{|c|}{ Time of experience in the pediatric area (years) } \\
\hline $2-5$ & $8(25.8)$ & \multirow{4}{*}{8.57} & \multirow{4}{*}{4.083} \\
\hline $6-10$ & 15 (48.4) & & \\
\hline $11-15$ & $6(19.3)$ & & \\
\hline More than 15 & $2(6.5)$ & & \\
\hline \multicolumn{4}{|c|}{ Length of service at the unit (years) } \\
\hline $2-4$ & $21(67.7)$ & \multirow{2}{*}{3.97} & \multirow[b]{2}{*}{1.497} \\
\hline $5-7$ & $10(32.3)$ & & \\
\hline
\end{tabular}


As for the care performed by professionals before the PIC, few of them cleaned their hands, and most evaluated the child's venous network (Table 2). It was observed that the professionals evaluated the child's venous network through the traditional clinical method, using the semiological resources of inspection and palpation with ambient light.

Regarding care during PIC, most professionals used procedure gloves, selected veins located in the antecubital fossa for catheterization, used limb tourniquet and, as a material for venous dilation, the latex glove, developed for professional protection while performing procedures. Still, 70\% alcohol was the most used solution for skin antisepsis, performing this technique with back-and-forth movements, but its evaporation time was not waited for the catheter insertion, and the catheterization site was touched after application of the antiseptic (Table 2).

It is noteworthy that, as mentioned above, the professionals did not use complementary methods to visualize the venous network (Table 2), they used a catheter over a 24-gauge needle, with a cannula made of polyurethane. Also, in all catheters, two-way extenders were attached, occluded with conventional caps.
As for post-PIC care, it was found that most catheters were stabilized and covered with IV-FIX, however, applying a strip of adhesive tape such as Micropore and/or adhesive tape for better fixation. In most intravenous devices, the identification tag of the catheterization site contained information such as date, catheter caliber and responsible for the PIC (Table 2 ).

Regarding the information about the registration of the procedure in the child's medical record, notes related to the date, time, caliber of the catheter and place of catheterization were observed as a standard of the researched unit.

\section{DISCUSSION}

To select the vein to be catheterized, it is essential to know the expected time for intravenous therapy ${ }^{(15-16)}$, the characteristics of the fluids that will be infused through the catheter (if irritating, vesicant), osmolarity ${ }^{(15-16)}$ and hydrogenic potential ${ }^{(16)}$, availability of peripheral veins ${ }^{(15,17)}$, history of previous punctures ${ }^{(16)}$, characteristics of the child's growth and development, as well as preparation for the procedure through an age-appropriate communication strategy of child.

Table 2 - Care Observed Before, During, and After Peripheral Intravenous Catheterization in Hospitalized Children, Feira de Santana, Bahia, Brazil, AprilJune of 2017

\begin{tabular}{|c|c|c|}
\hline & $\begin{array}{c}\text { Yes } \\
\text { n (\%) }\end{array}$ & $\begin{array}{l}\text { No } \\
\text { n (\%) }\end{array}$ \\
\hline $\begin{array}{l}\text { Care before peripheral intravenous catheterization } \\
\text { Sanitization of hands }\end{array}$ & 21 (33.9) & $41(66.1)$ \\
\hline Assessment of the conditions of the venous network? (visibility, palpability, path and mobility) & $60(96.8)$ & $2(3.2)$ \\
\hline Care during peripheral intravenous catheterization & & \\
\hline $\begin{array}{l}\text { Personal protective equipment used } \\
\text { Procedure gloves } \\
\text { Disposable mask }\end{array}$ & $\begin{array}{c}44(71) \\
19(30.6)\end{array}$ & $\begin{array}{c}18(29) \\
43(69.4)\end{array}$ \\
\hline $\begin{array}{l}\text { Area used for peripheral intravenous catheterization } \\
\text { Hands } \\
\text { Forearm } \\
\text { Antecubital fossa } \\
\text { Feet }\end{array}$ & $\begin{aligned} 20 & (32.6) \\
15 & (24.2) \\
22 & (35.5) \\
5 & (8.1)\end{aligned}$ & $\begin{array}{l}- \\
- \\
-\end{array}$ \\
\hline Vein dilation & $62(100)$ & - \\
\hline $\begin{array}{l}\text { Material used for vein dilation } \\
\text { Latex Procedure Glove }\end{array}$ & $62(100)$ & - \\
\hline $\begin{array}{l}\text { Material used for antisepsis of the catheter insertion site } \\
\text { Cotton }\end{array}$ & $62(100)$ & - \\
\hline $\begin{array}{l}\text { Technique used for antisepsis of the catheter insertion site } \\
\text { Back and forth movement }\end{array}$ & $62(100)$ & - \\
\hline $\begin{array}{l}\text { Solution used for antisepsis of the catheter insertion site } \\
0.5 \% \text { alcoholic chlorhexidine } \\
70 \% \text { alcohol } \%\end{array}$ & $\begin{array}{l}13(21) \\
49(79)\end{array}$ & - \\
\hline Waited the time for the antiseptic to dry & $14(22.6)$ & $48(77.4)$ \\
\hline Touched the insertion site after antisepsis & $33(53.2)$ & $29(46.8)$ \\
\hline Using equipment to visualize the vein during peripheral intravenous catheterization & - & $62(100)$ \\
\hline Stabilized the catheter after peripheral intravenous catheterization & $57(91.9)$ & $5(8.1)$ \\
\hline $\begin{array}{l}\text { Covers used over the intravenous catheter } \\
\text { IV-FIX }+ \text { Micropore }{ }^{\oplus} \text { type adhesive tape } \\
\text { IV-FIX }+ \text { Adhesive Tape Type } \\
\text { Micropore } \\
\text { IV-FIX } \text { type adhesive tape + sterile gauze }^{\circledast}+\text { Micropore }^{\oplus} \text { Type Adhesive Tape + Adhesive Tape Type }\end{array}$ & $\begin{array}{l}29(46.8) \\
8(12.9) \\
1(1.6) \\
24(38.7)\end{array}$ & $\begin{array}{l}- \\
- \\
-\end{array}$ \\
\hline Care after peripheral intravenous catheterization & & \\
\hline $\begin{array}{l}\text { Information entered on the peripheral intravenous catheterization identification tag } \\
\text { Procedure date } \\
\text { Procedure time } \\
\text { Catheter gauge } \\
\text { Responsible professional }\end{array}$ & $\begin{array}{l}61(98.4) \\
11(17.7) \\
52(83.9) \\
58(93.5)\end{array}$ & $\begin{aligned} 1 & (1.6) \\
51 & (82.3) \\
10 & (16.1) \\
4 & (6.5)\end{aligned}$ \\
\hline
\end{tabular}


Knowledge of pharmacological principles, anatomical and physiological bases of the venous network and decision-making related to IVT are acquired during nursing education, highlighting the need for the development of skills, competences and clinical reasoning of this professional to carry out of PIC in children ${ }^{(19)}$. However, the PICs observed in this research were carried out only by nursing technicians, without the direct supervision of the nurse.

The data from the present research point to the provision of care before, during and after the PIC that is not based on worldwide recognized standards of practice, which may contribute to complications related to IVT and put the safety of the patient undergoing this therapy at risk. With data analysis, a high percentage of care measures that diverged from the recommendations were observed - for example, hand hygiene and proper use of antiseptic ${ }^{(15-17)}$.

A descriptive and exploratory study developed in neonatal and pediatric intensive care units in São Paulo identified that professionals cleaned their hands immediately before puncture and evaluation of the venous network, after catheter stabilization and after the end of the procedure ${ }^{(20)}$.

Hand hygiene is a simple preventive measure of relevance in health care, and failures in its implementation are closely related to infections acquired in the hospital environment ${ }^{(21)}$ and with the possibility of contamination of the catheter insertion site, being a measure recommended during PIC and catheter maintenance ${ }^{(15-16,21)}$. In the researched unit, there was a sink for hand hygiene in each ward and an alcohol gel dispenser, which could contribute to adherence to hand hygiene by the health professionals of the service.

In the present study, low adherence to the use of personal protective equipment (PPE) was also observed ${ }^{(20,22)}$, such as gloves ${ }^{(15)}$. Mask use was identified during PIC, although the recommendation is only during insertion of central venous catheters ${ }^{(17)}$. It is noteworthy that PPE are considered barriers that, when combined with hand hygiene, interfere in the transmission chain of microorganisms and prevent infections related to health care, in addition to protecting health professionals against possible occupational contamination during the provision of care ${ }^{(16)}$.

An observational study on the practices of professionals during venipuncture to collect a blood sample identified a low rate of hand hygiene $(28 \%)$, the use of gloves $(20 \%)$ and the use of antiseptic (44.4\%), indicating the urgent need for professional training to improve practice, patient safety and quality of care ${ }^{(23)}$.

Another important practice to be performed before performing the PIC is the care provided by the professional with the choice of the catheter insertion site. It is recommended that the inspection of the skin conditions be carried out, aiming to evaluate and choose a site that does not present lesions ${ }^{(9)}$ resulting from previous PIC attempts or with veins compromised by complications such as infiltration, extravasation, phlebitis and hematoma ${ }^{(15)}$.

It is also recommended to evaluate the conditions of the venous network regarding its visibility, path, depth ${ }^{(16)}$, palpability and mobility, as well as considering the nature of the drugs and solutions to be administered, infusion flow and volume in the vessel selection, general conditions of the vein and duration of IVT ${ }^{(15)}$.

In selecting the insertion site, after carefully observing the conditions of the venous network, the professionals started the punctures through the antecubital fossa and subsequently accessed the veins in the hands, similar to other studies ${ }^{(20,22)}$. According to INS Brazil ${ }^{(16)}$, the first attempt at PIC should start from the most distal region, considering the particularities of each drug and the possibilities of complications. In turn, the American INS ${ }^{(15)}$ suggests the use of veins in the hand, forearm and upper arm below the armpit, avoiding flexion areas, so as not to limit the child's movement.

Thus, the site selected for catheterization identified in this study can be justified by the fact that veins on the back of the hand are more visible and palpable and that those located in the antecubital fossa, in addition to being easily identified, are also the thickest. In addition, the absence of equipment that collaborates with the visualization and assessment of the conditions of the vein, such as devices that emit infrared or near-infrared light, transillumination or ultrasound, can make professionals prefer the veins in these sites due to easy clinical assessment.

However, the American INS ${ }^{(15)}$ suggests that veins in the antecubital fossa are avoided as sites for PIC because they limit the child's movements. According to some studies, the insertion of catheters into the veins of the antecubital fossa ${ }^{(24)}$ and the dorsum of the hand ${ }^{(5)}$ generates a higher occurrence of complications, such as infiltration ${ }^{(1,24)}$, extravasation ${ }^{(25)}$ and phlebitis ${ }^{(26-27)}$.

As for vessel dilation to improve visualization, the participants used the limb garroting with a latex glove, and this can also be seen in another national survey that highlighted the use of this technique by almost all participants, being performed immediately before the $\mathrm{PIC}^{(21)}$. Research carried out in Portugal on the practices of nurses related to the insertion and maintenance of peripheral venous catheters in adults identified that reusable materials were used for limb tourniquet and without any prior attempt at decontamination in all situations observed ${ }^{(28)}$.

The American INS ${ }^{(15)}$ recommends the use of single-use tourniquets, as such supplies should not be shared in clinical practice due to contamination by pathogens with a resistance profile to antibiotics widely used in hospital institutions, such as coagulasenegative Staphylococcus, Staphylococcus aureus, Rodothorula, mucilaginosa, Candida albicans and Staphylococcus spp ${ }^{(29)}$. Therefore, this may have repercussions on patient safety, given the type of material and microbiota found ${ }^{(30)}$.

The preparation of the insertion site is essential to prevent infection, as the insertion site becomes colonized by bacteria from the skin of the child or health professional, making the use of an antiseptic solution, if necessary ${ }^{(17)}$.

Thus, in this study, the professionals observed used $70 \%$ alcohol as an antiseptic and, less frequently, alcoholic chlorhexidine $0.5 \%$, a finding similar to that of another study ${ }^{(20)}$. However, a Canadian research carried out in a Neonatal Intensive Care Unit found a higher percentage of use of chlorhexidine gluconate compared to isopropyl alcohol ${ }^{(31)}$, and all these antiseptic solutions can be used at the time of CIP(15-17).

With regard to the preparation of the catheter insertion site, the aseptic technique used did not follow all the recommendations of the practice standards of the American INS ${ }^{(15)}$, INS Brazil(16) and the National Health Surveillance Agency(18), as the antiseptic drying time was not respected most of the time. Depending on the type of antiseptic solution, it is recommended to wait from 
five seconds to two minutes for the antiseptic to dry before catheterization ${ }^{(15-16)}$. When this care is not properly followed, chemical phlebitis can occur due to the introduction of the catheter through the skin with product residues, causing its penetration into the bloodstream and consequent damage to the vascular endothelium, not to mention the increased risk of infection ${ }^{(15)}$.

Associated with the proper use of the antiseptic solution, the no touch technique is recommended, characterized by the absence of touch on the skin at the site of insertion of the intravenous catheter after application of the antiseptic; and if there is a need for palpation, sterile gloves should be used ${ }^{(15-17)}$. However, in the present study, most participants touched the catheterization site after skin antisepsis. The absence of both waiting for the antiseptic to dry and the no touch technique was identified in a survey conducted in Portugal, according to which $21.1 \%$ and $44.7 \%$ of professionals, respectively, did not wait for the antiseptic to dry and touched the puncture site after its application ${ }^{(28)}$. Failure to take these precautions can result in ineffective antisepsis, which may evolve to bloodstream infections and other complications during IVT.

As mentioned, the use of complementary methods to visualize the venous network - such as a device with infrared light emission, ultrasound, among others - could facilitate this process, so that professionals would not need to touch the puncture site again to confirm the positioning of the vase ${ }^{(32)}$.

After the PIC, the professionals stabilized the catheter with IVFix in most observations and also used hypoallergenic adhesive tapes such as Micropore and/or adhesive tape, in order to avoid accidental removal of the catheter and because they believed it would be safer. It is worth noting that the stabilization of the catheter minimizes displacements of its tip inside the vessel, preventing loss and migration of catheters and complications at the catheterization sites ${ }^{(15-17)}$. Complications such as infiltration ${ }^{(2)}$, local or bloodstream infections ${ }^{(16)}$ can also be minimized by using sterile dressings. However, it is not recommended to use nonsterile adhesive tapes to stabilize peripheral catheters, as they can be easily contaminated with pathogenic microorganisms ${ }^{(15-17)}$. Furthermore, depending on how the stabilization and coverage of the catheter are performed, the visibility of the insertion site and the early identification of complications related to the IVT can be compromised ${ }^{(20,33)}$. Thus, it is recommended to use material that is specifically designed and developed to control the movement of the catheter and that favors constant visualization of the insertion site s(15-17). $^{(1)}$.

Meta-analysis ${ }^{(4)}$ aimed to evaluate the influence of coverage and fixation of peripheral intravenous devices in children on the occurrence of failures such as complications of IVT and accidental removal. Transparent dressings versus gauze were investigated as coverings; transparent bandages with edges versus a fixation device; transparent bandages with edges versus adhesive tape; transparent dressings versus adhesive tape. The authors found that there is no evidence to highlight the superiority of these materials in preventing complications related to PIC.

Thus, it is necessary to incorporate the concepts of stabilization and safe coverage in the researched context, in order to obtain the best care results, properly using available resources, such as sterile adhesives with properties that facilitate stabilization, secure coverage and continuous visualization of the site insertion of the device ${ }^{(15)}$. In the researched unit, there is no protocol for stabilization and coverage of peripheral intravenous catheters, and the availability of IV-Fix and rolls of adhesive tapes of the Micropore type and/ or adhesive tape was observed, with the choice of the material to be used at the professional's discretion after PIC.

Regarding the information entered on the PIC identification label, INS Brazil ${ }^{(16)}$ recommends recording the date and the person responsible for the procedure, and these data are observed in this research.

When recording the date of insertion of the catheter, there is later a reflection on both accidental and scheduled removal of the catheter, due to the time of use and the reasons for removal, as these can reveal possible adverse events. A study of nine clinical, randomized and controlled trials involving 7,412 participants showed a lack of clarity in the difference in rates of catheter-related bloodstream infection, thrombophlebitis, mortality and pain in patients whose catheters were removed by clinical indication or routinely replaced ${ }^{(33)}$.

As a result of a meta-analysis, there is evidence of moderate certainty that the occurrence of infiltration and occlusion of catheters is probably lower when the catheter is routinely removed, although the recommendations indicate removal only for clinical indication ${ }^{(33)}$. In this sense, the need for proper selection of the vein and correct stabilization and coverage of the catheter is highlighted as essential measures for the prevention of these complications, as well as the proper maintenance of the catheter, following the current recommendations ${ }^{(15-17)}$.

Knowing that the longer period of permanence of the intravascular catheter, free from complications, should be one of the main goals of the nursing team in child care with peripheral intravenous catheters and that, in clinical practice, professionals find it difficult to maintain these catheters in this clientele over the days of hospitalization ${ }^{(16)}$, it is essential that measures are implemented to promote child safety and improve care outcomes.

In view of the data presented, it is necessary to organize IVT teams made up of health professionals with a high degree of clinical expertise in the selection, insertion, stabilization, coverage and maintenance of peripheral intravenous catheters in children. These teams contribute to the reduction of infectious and mechanical complications related to intravascular devices; promote comfort related to fewer puncture attempts, quality and safety in patient care; and elaborate protocols related to the practice of IVT ${ }^{(15-16)}$

However, in the researched unit, there are no specialized groups in IVT, and the formation and support of this group would have the consequence of improving the quality of care and reducing complications related to IVT in hospitalized children.

In addition, these professionals need to be qualified to provide safe care regarding the CIP, as well as standardize procedures, develop protocols, standard operating procedures, ckecklists or bundles as strategies for the dissemination and implementation of current evidence in the researched unit, aiming to support nursing care for the child. In addition to continuing education, the need for institutions to offer the professional physical structure, appropriate technologies and supplies is highlighted so that they can provide the pediatric patient with safe and qualified care, in 
addition to the possibility of direct work and supervision of the nurse in childcare.

\section{Study limitations}

This research has some limitations: the convenience sample; the performance in a single unit of the researched hospital; and the fact that it is descriptive.

\section{Contributions to the field of nursing}

The results present contributions to the theoretical, practical and social context. For the scientific community, the data will strengthen the literature regarding the knowledge of care performed before, during and after PIC in children. In the context of practice, the importance of understanding how the translation of scientific evidence in the care with the insertion of peripheral intravascular catheters is highlighted, considering the development of strategies that can reduce gaps, narrow the relationship between theory and practice, contributing to patient safety.

Thus, as already mentioned, it is necessary that the professionals of the nursing team can be qualified in terms of the best practices for PIC in children. Also, in order for this procedure to be performed safely, it is necessary to standardize fundamental care through the development of protocols or standard operating procedures supported by scientific evidence and through the use of clinical tools such as ckecklist and bundles for the implementation of the proposed standards.

In the social sphere, we think about the empowerment of the nursing professional in the sense of taking responsibility for planning the performance of peripheral TIV in a safe way.

\section{CONCLUSIONS}

This study made it possible to observe little care supported by scientific evidence performed by nursing technicians, demonstrating low adherence of professionals to hand hygiene, unnecessary use of disposable mask, problems in selecting the catheter insertion site, performing skin antisepsis and covering the catheter. Thus, weaknesses in the care provided to the child before, during and after the PIC were revealed, in addition to gaps in care practice that need to be addressed.

Therefore, it is necessary to: explore factors associated with the low articulation of the recommendations of the American INS, INS Brazil and ANVISA for the realization of the PIC in the context studied with the practices observed in the health service; and advance in the implementation of measures that promote and sustain safe care for children using peripheral IVT.

\section{REFERENCES}

1. Ullman AJ, Kleidon T, Cooke M, Rickard CM. Road map for improvement: point prevalence audit and survey of central venous access devices in paediatric acute care. J Paed Child Health. 2017;53(2):123-30. https://doi.org/10.1111/jpc.13347

2. Jeong IS, Jeon GR, Lee MS, Shin BJ, Kim YJ, Park SM, et al. Intravenous infiltration risk by catheter dwell time among hospitalized children. J Pediatr Nurs. 2017;32:47-51. https://doi.org/10.1016/j.pedn.2016.08.008

3. Ullman AJ, Takashima M, Kleidon T, Ray-Barruel G, Alexandrou E, Rickard CM. Global pediatric peripheral intravenous catheter practice and performance: a secondary analysis of 4206 catheters. J Pediatr Nurs. 2020;50:e18-e25. https://doi.org/10.1016/j.pedn.2019.09.023

4. Marsh N, Webster J, Mihala G, Rickard CM. Devices and dressings to secure peripheral venous catheters: a Cochrane systematic review and meta-analysis. Int J Nurs Stud. 2017;67:12-9. https://doi.org/10.1016/j.jnurstu.2016.11.007

5. Ben Abdelaziz R, Hafsi H, Hajji H, Boudabous H, Ben Chehida A, Mrabet A, et al. Peripheral Venous catheter complications in children: predisposing factors in a multicenter prospective cohort study. BMC Pediatr. 2017;17(1):208. https://doi.org/10.1186/s12887-017-0965-y

6. Odom B, Lowe L, Yates C. Peripheral infiltration and extravasation injury methodology: a retrospective study. J Infus Nurs. 2018;41(4):24752. https://doi.org/10.1097/NAN.0000000000000287

7. Tuffaha HW, Marsh N, Byrnes J, Gavin N, Webster J, Cooke M, et al. Cost of vascular access devices in public hospitals in Queensland. Austral Health Rev. 2018;43(5):511-5. https://doi.org/10.1071/AH18102

8. Melo EM, Aragão AL, Pessoa CMP, Lima FET, Barbosa IV, Studart RMB. [Care provided by nursing staff during the peripheral venipuncture procedure]. Rev Enferm UFPE. 2015;9(3):1022-30. https://doi.org/2015. 10.5205/reuol.7505-65182-1-RV.0903201502 Portuguese.

9. Machado MH. Perfil da enfermagem no Brasil: relatório final. Rio de Janeiro: NERHUS - DAPS - ENSP/Fiocruz. 2017.

10. Araújo MS, Medeiros SM, Costa EO, Oliveira JSA, Costa RRO, Sousa YG. Analysis of the guiding rules of the nurse technician's practice in Brazil. Rev Bras Enferm. 2020;73(3):e20180322. https://doi.org/10.1590/0034-7167-2018-0322

11. Ministério da Educação (BR). Resolução n 7, de 18 de abril de 1977. Padrões mínimos: curso de técnicos e auxiliares de enfermagem. Diário Oficial da União. 1977.

12. Ministério da Educação (BR). Lei n 7.498/86, de 25 de junho de 1986. Dispõe sobre a regulamentação do exercício da Enfermagem e dá outras providências. Diário Oficial da União de 26 de junho de 1986. Seção I, p. 9.273-9.275.

13. Sassaki RL, Perroca MG. Interruptions and their effects on the dynamics of the nursing work. Rev Gaúcha Enferm. 2017;38(2):e67284. https:// doi.org/10.1590/1983-1447.2017.02.67284

14. von Elm E, Altman DG, Egger M, Pocock SJ, Gøtzsche PC, STROBE Initiative. Strengthening the Reporting of Observational Studies in Epidemiology (STROBE) statement: guidelines for reporting observational studies. BMJ. 2007;335(7624):806-8. https://doi.org/10.1136/bmj.39335.541782.AD 
15. Gorski L, Hadaway L, Hagle ME, McGoldrick M, Orr M, Doellman D. Infusion Therapy Standards of Practice. J Infus Nurs. 2016;39(1s):1-169. https://doi.org/10.1097/NHH.0000000000000481

16. Infusion Nurses Society Brasil. Diretrizes práticas para a terapia infusional. $3^{\text {a }}$ ed. São Paulo; 2018.

17. Agência Nacional de Vigilância Sanitária. Medidas de Prevenção de Infecção Relacionada à Assistência à Saúde. $2^{\mathrm{a}}$ ed. Brasília; 2017.

18. Cavadas LF, Ponte C, Granja M. Estudantes de medicina como colaboradores na investigação em centros de saúde. Rev Port Med Geral Fam. 2018;34(6):428-36. https://doi.org/10.32385/rpmgf.v34i6.12335

19. Coimbra JAH, Cassiani SHB. Responsabilidade da enfermagem na administração de medicamentos: algumas reflexões para uma prática segura com qualidade de assistência. Rev Latino-Am Enfermagem [Internet]. 2001[cited 2021 Mar 09];9(2):56-60. Available from: https:// www.revistas.usp.br/rlae/article/view/1552/1597

20. Nakandakari RA, Balieiro MM, Anacleto AS, Kusahara DM, Avelar AFM. Nursing practices related to peripheral intravenous catheterization in newborns and children. Rev Soc Bras Enf Ped. 2018;18(1):29-36. https://doi.org/10.31508/1676-3793201800005

21. Dourado SBPB. [Hand hygiene: its effects on infection indices and hospital costs]. Rev Enferm UFPE. 2016;10(4):3585-92. https://doi. org/10.5205/1981-8963-v10i4a11133p3585-3592-2016 Portuguese

22. Passos EAD, Marziale MHP. Knowledge and attitudes of nursing professionals at a hospital in the brazilian state of São Paulo regarding standard precautions. Cogitare Enferm. 2020;25. https://doi.org/10.5380/ce.v25i0.66744

23. Merzougui L, Chebi D, Rjeb MB, Ouness SB, Khafacha S, Dhidah L, Laatiri HS. Medical pratice assessment during the phlebotomy: clinical audit of blood sampling. Tunis Med. 2018;96(5):287-92.

24. Høvik LH, Gjeilo KH, Lydersen S. Monitoring quality of care for peripheral intravenous catheters; feasibility and reliability of the peripheral intravenous catheters mini questionnaire (PIVC-miniQ). BMC Health Serv Res. 2019;19(636). https://doi.org/10.1186/s12913-019-4497-z

25. Fonzo-Christe C, Parron A, Combescure C, Rimensberger PC, Pfister RE, Bonnabry P. Younger age and in situ duration of peripheral intravenous catheters were risk factors for extravasation in a retrospective paediatric study. Acta Paediatr. 2018;107(7):1240-6. https://doi. org/10.1111/apa.14280

26. Chang WP, Peng YX. Occurrence of phlebitis: a systematic review and meta-analysis. Meta-Analysis J Nurs Res. 2018;67(3):252-60. https://doi. org/10.1097/NNR.0000000000000279

27. Comparcini D, Simonetti V, Blot S, Tomietto M, Cicolini G. Relationship between peripheral insertion site and catheter-related phlebitis in adult hospitalized patients: a systematic review. Review Prof Inferm. 2017;70(1):51-60. https://doi.org/10.7429/pi.2017.701051

28. Oliveira ASS, Costa PJS, Graveto JMGN, Costa FJG, Osório NIA, Cosme ASTC, et al. Nurses' peripheral intravenous catheter-related practices: a descriptive study. Rev Enferm Ref. 2019;4(21):111-22. https://doi.org/10.12707/RIV19006

29. Salgueiro-Oliveira ASS, Costa PJS, Braga LM, Graveto JMGN, Oliveira VS, Parreira PMSD. Health professionals' practices related with tourniquet use during peripheral venipuncture: a scoping review. Rev Latino-Am Enfermagem. 2019;27:e3125. https://doi. org/10.1590/1518-8345.2743-3125

30. Batista KC, Tipple AF, Leão-Vasconcelos LS, Ribeiro EL, Prado MA. Contamination of tourniquets for peripheral intravenous puncture. Acta Paul Enferm. 2015;28(5):426-32. https://doi.org/10.1590/1982-0194201500072

31. McCord H, Fieldhouse E, El-Naggar W. Current practices of antiseptic use in Canadian neonatal intensive care units. Am J Perinatol 2019;36(02):141-7. https://doi.org/10.1055/s-0038-1661406

32. Santos LM, Santos SA, Silva BSM, Santana RCB, Avelar AFM. Influência de tecnologias para avaliação/visualização vascular no cateterismo intravenoso periférico: revisão integrativa. Esc Anna Nery. 2020;24(3):e20190355. https://doi.org/10.1590/2177-9465-ean-2019-0355

33. Webster J, Osborne S, Rickard CM, Marsh N. Clinically-indicated replacement versus routine replacement of peripheral venous catheters. Cochrane Database Syst Rev. 2019;1:CD007798. https://doi.org/10.1002/14651858.CD007798.pub5 